\title{
Inclusion of cytoplasmic lineage effect and direct-maternal genetic covariance for genetic evaluation of growth traits in Nellore cattle
}

L. Grigoletto ${ }^{1}$, E.C. Mattos ${ }^{1}$, M.H.A. Santana ${ }^{1}$, F. Baldi ${ }^{2}$, J.P. Eler ${ }^{1}$ and J.B.S. Ferraz

${ }^{1}$ Departamento de Ciências Básicas, Faculdade de Zootecnia e Engenharia de Alimentos, Universidade de São Paulo, Pirassununga, SP, Brasil

${ }^{2}$ Departamento de Zootecnia, Faculdade de Ciências Agrárias e Veterinárias, Universidade Estadual Paulista, Jaboticabal, SP, Brasil

Corresponding author: L. Grigoletto

E-mail: lgrigoletto@usp.br

Genet. Mol. Res. 15 (3): gmr.15038812

Received May 16, 2016

Accepted June 22, 2016

Published August 18, 2016

DOI http://dx.doi.org/10.4238/gmr.15038812

Copyright (C 2016 The Authors. This is an open-access article distributed under the terms of the Creative Commons Attribution ShareAlike (CC BY-SA) 4.0 License.

\begin{abstract}
We evaluated the impact of cytoplasmic lineage effects (Lc) for growth traits on genetic evaluation, including the genetic covariance between direct and maternal effects $\left(\sigma_{\mathrm{am}}\right)$. Pedigree data from 496,190 Nellore animals and observations on birth weight (BW, $\mathrm{N}=243,391$ ), weaning weight (WW, $\mathrm{N}=431,681$ ), and post-weaning weight gain adjusted to 345 days (PWG, $\mathrm{N}=172,131$ ) were analyzed. Four univariate models were used to obtain estimates of (co)variance components using the restricted maximum likelihood method in the BLUPF90 program. Model 1 included Lc and $\sigma_{\text {am }}$. Model 2 included Lc and $\sigma_{a \mathrm{~m}}$ was set to zero. Model 3 did not include Lc. Model 4 did not include $\mathrm{Lc}$ and $\sigma_{\mathrm{am}}$ was set to zero. These models considered the effects
\end{abstract}


of the Lc as random. Phenotypic variance obtained through cytoplasmic lineage effects was determined for all traits, ranging from 0.07 to 0.15 , 0.15 to 0.03 , and 0.05 to $0.03 \%$ for $\mathrm{BW}, \mathrm{WW}$, and PWG, respectively, for models 1 and 2. Correlations between direct and maternal genetic components were positive for WW and negative for BW and PWG. No differences were observed for genetic parameter estimates or animal ranking with the inclusion of $\sigma_{\mathrm{am}}$. For BW, the likelihood ratio suggested that model 1 best fits the data, while model 4 was the most appropriate for WW and PWG. Thus, these models are recommended for genetic evaluations. Despite the low magnitude of cytoplasmic lineages, this effect could predict breeding value and improve the selection of animals for BW in this Nellore population.

Key words: Cytoplasmic lineage effect; Direct-maternal covariance; Growth traits; Mitochondrial DNA; Nellore

\section{INTRODUCTION}

In beef cattle, the cytoplasmic effect, which occurs through the genetic effect of mitochondria, provides an important contribution to variation in growth traits. Cytoplasmic inheritance refers to the matrilineal transmission of mitochondrial DNA (mtDNA), an extranuclear genetic material, through the oocyte cytoplasm (Brown et al., 1989). The maternal contribution to the animal's genotype considers half of their direct additive genetic component added to the permanent maternal environmental and cytoplasmic effect. Thus, maternal contribution affects progeny performance from embryonic development up to the expression of post-weaning traits in each animal and in future generations. Several studies have shown that cytoplasmic effect has a small influence on the genetic variation for pre weaning and reproductive traits in beef cattle (Tess and MacNeil, 1994; Gibson et al., 1997; Mezzadra et al., 2005; Quintino et al., 2009; Garmyn et al., 2011; Bueno et al., 2012; Carrillo and Siewerdt, 2012; Pun et al., 2012; Neser et al., 2014).

In general, in beef cattle breeding programs, maternal effects and direct-maternal genetic covariance are used in genetic models for the genetic evaluation of pre-weaning traits. According to Maniatis and Pollott (2003), when these effects are ignored, the model might underestimate the genetic responses. In this respect, Clément et al. (2001) used simulated data to show that the omission of existing maternal genetic effects leads to overestimation of direct heritability, which is over two-fold in some cases.

For some traits and breeds, the direct and maternal genetic covariance are not assumed in models used for genetic evaluation. The main argument is the difficulty for deriving direct and maternal effects allowing the correct formation of covariance structure (Meyer, 1992), besides the confused interpretation on animal selection caused by the negative genetic correlation between these effects, mainly pre-weaning traits. Estimates of negative correlations between direct and maternal effects have been reported by Eler et al. (2000), Cabrera et al. (2001), Ferreira et al. (2011), and Boligon et al. (2012) for Nellore cattle. However, there is no consensus on the incorporation of direct and maternal genetic covariance in the statistical models for genetic evaluation in Nellore cattle.

The quality of the pedigree and phenotypic information affect the estimates of genetic

Genetics and Molecular Research 15 (3): gmr.15038812 
parameters and the prediction of breeding values with direct and maternal effects (Gerstmayr, 1992; Clément et al., 2001; Malhado et al., 2004). In beef cattle, particularly under ranch conditions, pedigree information is scarce or with insufficient structure, and unknown sires or maternal-sires are common. The present study aimed to support the evaluation and improvement of genetic models for beef cattle with the incorporation of cytoplasmic lineage effects and direct-maternal genetic covariance on the estimation of (co)variance components and genetic parameters and on the prediction of breeding values for growth traits of Nellore cattle.

\section{MATERIAL AND METHODS}

\section{Data description}

A total of 496,190 Nellore animals, born between 1984 and 2013, from 2688 bulls and 134,728 cows, belonging to the Genetic Breeding Program of Agropecuária CFM Ltda., a company with farms in the Southeastern and Midwestern regions of Brazil, were utilized. Records of the following traits were analyzed: birth weight $(\mathrm{BW}, \mathrm{kg})$, weaning weight (WW, kg), and post-weaning weight gain adjusted to 345 days (PWG, kg) (Table 1). The analyses were performed together with the Research Center of Animal Breeding, Biotechnology and Transgenesis of the College of Animal Sciences and Food Engineering, Universidade de São Paulo, Brazil.

Table 1. Number of observations, mean, standard deviation (SD), number of contemporary groups (CG), number of cytoplasmic lineages (Lc), and number of generations from the datasets used for birth weight (BW), weaning weight $(\mathrm{WW})$ and post-weaning weight gain (PWG).

\begin{tabular}{l|c|c|c}
\hline Trait & BW (kg) & WW $(\mathrm{kg})$ & PWG $(\mathrm{kg})$ \\
\hline Number of observation & 243,391 & 431,681 & 172,131 \\
\hline Mean & 31.52 & 175.65 & 112.24 \\
\hline SD & 3.61 & 27.27 & 30.95 \\
\hline Number of CG & 4203 & 10,951 & 984 \\
\hline Number of Lc & 11,333 & 28,043 & 9,267 \\
\hline Number of generations & 1 to 8 & 1 to 9 & 1 to 7 \\
\hline
\end{tabular}

To identify the founding lineages specific to each generation, the LinMat software (Mourão et al., 2006) was used. This software traces the ancestral maternal lineage of the animal. In total, 28,459 ancestral cows were identified, and the longest ancestral time from the maternal line was nine generations. The total number of animals with records for maternal cytoplasmic lineage that could be considered for analysis is presented in Table 1. Only cytoplasmic lines with a number equal to or higher than three offspring were considered in the database. This was important to obtain the correct genetic covariance matrix as proposed by Dodenhoff et al. (1999).

Data consistency was ensured and animals without parental information, records, cytoplasmic lineage, age of cow at calving unknown, and animals with records considering three standard deviations from the mean were discarded. The data structure is summarized in Table 1. Computer programs Microsoft Visual FoxPro (version 9.0) and the software R (version 3.2.1) were used to prepare the files and to ensure data consistency.

Genetics and Molecular Research 15 (3): gmr.15038812 


\section{Analysis}

Four different models were fitted for all traits. The estimates of the (co)variance components were obtained with univariate models using the restricted maximum likelihood (REML) method by the BLUPF90 program (Misztal et al., 2007).

For WW, the contemporary group (CG), as a fixed effect, comprised the farm, sex, year of birth, and weaning management group (WMG), while for BW and PWG, farm, sex, and year of birth were considered for the CG. The number of generations was also considered a fixed effect, and the age of the dam, linear and quadratic effects, and linear effect of animal age, except for the BW, were considered as covariates.

Model 1: For each analyzed trait, this model included the direct additive genetic effect (a), maternal additive genetic effect $(\mathrm{m})$, covariance between these effects $\left(\sigma_{\mathrm{am}}\right)$, cytoplasmic lineage effect (Lc) as a random, permanent, maternal environment (c), and the residual effect (e). For PWG, the effect of the WMG (g) was incorporated as a random effect.

Model 2: the same as in Model 1, but did not include Lc.

Model 3: the same as in Model 1, but considering zero for $\sigma_{\mathrm{am}}$.

Model 4: the same as in Model 1, but did not include Lc and considering zero for $\sigma_{\mathrm{am}}$. The general model described was represented by the matrix notation below:

$$
\mathrm{Y}=\mathrm{X} b+\mathrm{Z}_{1} a+\mathrm{Z}_{2} m+\mathrm{Z}_{3} L c+\mathrm{Z}_{4} c+\mathrm{Z}_{5} g+e \quad \text { Equation } 1
$$

where $y$ is the vector for observations, $\mathrm{X}$ is the incidence matrix of fixed effects, $Z_{1}$ is the incidence matrix of animal additive genetic effects, $Z_{2}$ is the incidence matrix of maternal genetic effects, $Z_{3}$ is the incidence matrix of cytoplasmic line effects, $Z_{4}$ is the incidence matrix of permanent environmental effects associated with the dam, $Z_{5}$ is the incidence matrix of WMG, $b$ is the vector of fixed effects (contemporary group and number of generation), $a$ is the vector for random coefficients for direct additive effects, $m$ is the vector for random coefficients for additive maternal, $L c$ is the vector for random coefficients for cytoplasmic lineage effects, $c$ is the vector for random coefficients for maternal permanent environmental effects, $g$ is the vector for random coefficients for the WMG, and $e$ is the vector of residual effects.

The model assumed that

$$
V\left[\begin{array}{c}
a \\
m \\
l c \\
c \\
g \\
e
\end{array}\right]=\left[\begin{array}{cccccc}
A \sigma_{a}^{2} A \sigma_{a m} & 0 & 0 & 0 & 0 \\
A \sigma_{a m} A \sigma^{2} & 0 & 0 & 0 & 0 \\
0 & 0 & I N_{1} \sigma_{L c}^{2} & 0 & 0 & 0 \\
0 & 0 & 0 & I N_{2} \sigma_{c}^{2} & 0 & 0 \\
0 & 0 & 0 & 0 & I N_{3} \sigma_{g}^{2} & 0 \\
0 & 0 & 0 & 0 & 0 & I N \sigma_{e}^{2}
\end{array}\right],
$$

Equation 2

where $\mathrm{A}$ is the numerator relationship matrix among animals in the pedigree file, I is the identity matrix, $N_{1}, N_{2}$, and $N_{3}$ are the number of cytoplasmic lineages, dams, and WMG, respectively, $\mathrm{N}$ is number of records, $\sigma_{a}^{2}$ is the direct additive genetic variance, $\sigma_{m}^{2}$ is the maternal additive genetic variance, $\sigma_{a m}$ is the covariance between the direct and maternal genetic effects, $\sigma_{L c}^{2}$ is the variance of the cytoplasmic lineage effect, $\sigma_{c}^{2}$ is the permanent maternal environmental variance, and $\sigma_{e}^{2}$ is the residual variance.

To obtain direct heritability $\left[\mathrm{h}^{2}{ }_{\mathrm{a}}=\sigma_{\mathrm{a}}^{2} /\left(\sigma_{\mathrm{a}}^{2}+\sigma_{\mathrm{m}}^{2}+\sigma_{\mathrm{am}}+\sigma_{\mathrm{Lc}}^{2}+\sigma_{\mathrm{c}}^{2}+\sigma_{\mathrm{e}}^{2}\right)\right]$, maternal heritability $\left[\mathrm{h}_{\mathrm{m}}^{2}=\sigma_{\mathrm{m}}^{2} /\left(\sigma_{\mathrm{a}}^{2}+\sigma_{\mathrm{m}}^{2}+\sigma_{\mathrm{am}}+\sigma_{\mathrm{Lc}}^{2}+\sigma_{\mathrm{c}}^{2}+\sigma_{\mathrm{e}}^{2}\right)\right]$ and fraction of phenotypic variance due to permanent maternal environmental effects $\left[\mathrm{c}^{2}=\sigma_{\mathrm{c}}^{2} /\left(\sigma_{\mathrm{a}}^{2}+\sigma_{\mathrm{m}}^{2}+\sigma_{\mathrm{am}}+\sigma_{\mathrm{Lc}}^{2}+\sigma_{\mathrm{c}}^{2}+\sigma_{\mathrm{e}}^{2}\right)\right]$ on the estimated (co)variance components were used (Maniatis and Pollott, 2003). In addition, 
total heritability $\left(h^{2}\right)$ as defined by Willham (1972) was obtained through the calculation of the total direct additive variance as $\sigma_{\mathrm{t}}^{2}=\left(\sigma_{\mathrm{a}}^{2}+0.5 \sigma_{\mathrm{m}}^{2}+1.5 \sigma_{\mathrm{am}}\right)$.

The WMG was incorporated for PWG as a random effect in the models to increase the number of animals per CG, avoiding the elimination of important animals and the creation of CGs with small variability (Oliveira Júnior et al., 2014; Pedrosa et al., 2014b).

A likelihood ratio test (Rao and Scott, 1984) was used to compare the models. The difference between the $-2 \log$ values (Table 2) from the models was assumed to be distributed according to the chi-square test with one degree of freedom and a significance level of $\alpha=$ 0.05 . To verify the effect of the model on the animal classification, Spearman correlation coefficients were used to observe changes in breeding values predicted for traits based on models with and without the genetic covariance between direct and maternal effects.

Table 2. Likelihood function (-2log) for the models used for genetic evaluation for birth weight (BW), weaning weight (WW), and post-weaning weight gain (PWG).

\begin{tabular}{l|c|c|c|c}
\hline Models & M1 & M2 & M3 & M4 \\
\hline BW $(\mathrm{kg})$ & $686,612.8^{*}$ & $686,482.1$ & $686,487.1$ & $686,483.4$ \\
\hline$-2 \log$ & $2,748,081.2$ & $2,748,087.3$ & $2,748,108.0$ & $2,748,114.6^{*}$ \\
\hline WW $(\mathrm{kg})$ & & & \\
\hline$-2 \log$ & $1,051,340.9$ & $1,051,350.4$ & $1,051,373.3$ & $1,051,382.8^{*}$ \\
\hline PWG $(\mathrm{kg})$ & \multicolumn{5}{|l|}{}
\end{tabular}

*Model that better fitted the data sets for each trait analyzed. Model 1 (M1); Model 2 (M2); Model 3 (M3); Model 4 (M4).

\section{Results and discussion}

Descriptive statistics for BW, WW, and PWG are presented in Table 1. The means obtained for these traits were similar to those previously reported for Nellore cattle (Boligon et al., 2008, 2013; Pedrosa et al., 2014a).

With respect to the cytoplasmic lineage effect, for BW, there were statistical differences between models 3 and 2. This result was also observed for model 3 (with cytoplasmic effects and without direct-maternal genetic covariance) for WW and PWG in comparison to models 1 and 2 (Table 3).

Table 3. Comparison of $-2 \log$ differences between models, distributed according to the chi-square $\left(\chi^{2}\right)$ test*

\begin{tabular}{|c|c|c|c|}
\hline \multicolumn{4}{|c|}{ Trait } \\
\hline Difference between models $^{1}$ & BW & WW & PWG \\
\hline M1-M2 & $130.75^{* *}$ & -6.1 & -9.5 \\
\hline M1-M3 & $125.75^{* *}$ & -26.8 & -32.4 \\
\hline M1-M4 & $129.45 * *$ & -33.4 & -41.9 \\
\hline M2-M1 & -130.7 & $6.1^{* *}$ & $9.5^{* *}$ \\
\hline M2-M3 & -5.0 & -20.7 & -22.9 \\
\hline M2-M4 & -1.3 & -27.3 & -32.4 \\
\hline M3-M1 & -125.75 & $26.8^{* *}$ & $32.4^{* *}$ \\
\hline M3-M2 & $5.0^{* *}$ & $20.7^{* *}$ & $22.9 * *$ \\
\hline M3-M4 & 3.7 & -6.6 & -9.5 \\
\hline M4-M1 & -129.45 & $33.4 * *$ & $41.9 * *$ \\
\hline M4-M2 & 1.3 & $27.3^{* *}$ & $32.4^{* *}$ \\
\hline M4-M3 & -3.7 & $6.6^{* *}$ & $9.5^{* *}$ \\
\hline
\end{tabular}

Genetics and Molecular Research 15 (3): gmr.15038812 
However, model 1 was the most appropriate for BW (complete model) indicating the importance of the incorporated effects, while for WW and PWG, model 4 was more significant than other models considering the $-2 \log$ difference.

Differences between models were observed for the (co)variance components and genetic parameters (Table 4 and 5). Low values for cytoplasmic lineage effects were observed between models 1 and 3, ranging from 0.07 to $0.15,0.15$ to 0.03 , and 0.05 to $0.03 \%$ for $\mathrm{BW}$, WW, and PWG, respectively, as a proportion of phenotypic variance. However, the inclusion of cytoplasmic lineage effects is important for the genetic evaluation of the BW trait. Similar results were reported by Ventura et al. (2007), Quintino et al. (2009), and Bueno et al. (2012) in Nellore cattle.

Table 4. Estimates of (co)variance components for birth weight (BW), weaning weight (WW), and post weight gain adjusted to 345 days (PWG) calculated with the models studied.

\begin{tabular}{|c|c|c|c|c|c|c|c|c|c|}
\hline Traits & Models & $\sigma_{\mathrm{a}}^{2}$ & $\sigma^{2} \mathrm{~m}$ & $\sigma_{\mathrm{am}}$ & $\sigma^{2} \mathrm{lc}$ & $\sigma^{2} \mathrm{c}$ & $\sigma_{g}^{2}$ & $\sigma^{2} \mathrm{e}$ & $\sigma_{p}^{2}$ \\
\hline \multirow[t]{4}{*}{ BW } & M1 & 2.04 & 0.37 & -0.05 & 0.006 & 0.29 & - & 6.37 & 9.02 \\
\hline & M2 & 2.04 & 0.39 & -0.05 & - & 0.29 & - & 6.37 & 9.04 \\
\hline & M3 & 1.96 & 0.35 & 0.00 & 0.014 & 0.29 & - & 6.42 & 9.03 \\
\hline & M4 & 1.96 & 0.38 & 0.00 & - & 0.27 & - & 6.42 & 9.03 \\
\hline \multirow[t]{4}{*}{ WW } & M1 & 58.46 & 21.67 & 5.03 & 0.47 & 49.47 & - & 188.00 & 323.10 \\
\hline & M2 & 58.33 & 22.33 & 5.26 & - & 49.12 & - & 188.10 & 323.14 \\
\hline & M3 & 64.61 & 23.96 & 0.00 & 0.10 & 50.14 & - & 184.00 & 322.81 \\
\hline & M4 & 64.22 & 24.80 & 0.00 & - & 49.67 & - & 184.20 & 322.89 \\
\hline \multirow[t]{4}{*}{ PWG } & M1 & 61.55 & 8.43 & -9.42 & 0.20 & 9.03 & 76.59 & 255.90 & 402.28 \\
\hline & M2 & 61.54 & 8.52 & -9.16 & - & 8.83 & 76.59 & 256.00 & 402.32 \\
\hline & M3 & 47.47 & 5.54 & 0.00 & 0.13 & 7.04 & 76.74 & 264.50 & 401.42 \\
\hline & M4 & 47.55 & 5.61 & 0.00 & - & 7.12 & 76.74 & 264.40 & 401.42 \\
\hline
\end{tabular}

$\sigma_{\mathrm{a}}^{2}=$ direct additive genetic variance; $\sigma_{\mathrm{m}}^{2}=$ maternal genetic variance; $\sigma_{\mathrm{am}}=$ direct and maternal covariance; $\sigma_{\mathrm{lc}}^{2}=$ cytoplasmic lineage effect variance; $\sigma_{\mathrm{c}}^{2}=$ variance due to maternal permanent environmental effects; $\sigma_{\mathrm{e}}^{2}=$ residual variance; $\sigma_{\mathrm{p}}^{2}=$ phenotypic variance.

Table 5. Estimates of genetic parameters (SE in parenthesis) from univariate analysis of birth weight (BW), weaning weight (WW), and post weight gain adjusted to 345 days (PWG).

\begin{tabular}{|c|c|c|c|c|c|c|c|}
\hline Traits & Models & $\mathrm{h}^{2}{ }_{\mathrm{a}}$ & $\mathrm{h}^{2} \mathrm{~m}$ & $\mathrm{~h}^{2} \mathrm{t}$ & $\mathrm{ram}_{\mathrm{am}}$ & $\mathrm{Lc}^{2}$ & $\mathrm{c}^{2}$ \\
\hline \multirow[t]{4}{*}{$\mathrm{BW}$} & M1 & $0.23(0.03)$ & $0.04(0.01)$ & 0.24 & $-0.05(0.01)$ & $0.0007(0.001)$ & $0.03(0.01)$ \\
\hline & M2 & $0.22(0.03)$ & $0.04(0.01)$ & 0.24 & $-0.05(0.01)$ & 0.00 & $0.03(0.01)$ \\
\hline & M3 & $0.22(0.03)$ & $0.04(0.01)$ & 0.24 & 0.00 & $0.0015(0.002)$ & $0.03(0.01)$ \\
\hline & M4 & $0.22(0.03)$ & $0.04(0.01)$ & 0.24 & 0.00 & 0.00 & $0.03(0.01)$ \\
\hline \multirow[t]{4}{*}{ WW } & M1 & $0.18(0.02)$ & $0.07(0.01)$ & 0.22 & $0.14(0.01)$ & $0.0015(0.005)$ & $0.15(0.01)$ \\
\hline & M2 & $0.18(0.02)$ & $0.07(0.01)$ & 0.24 & $0.14(0.01)$ & 0.00 & $0.15(0.01)$ \\
\hline & M3 & $0.20(0.02)$ & $0.07(0.01)$ & 0.24 & 0.00 & $0.0003(0.001)$ & $0.15(0.01)$ \\
\hline & M4 & $0.20(0.02)$ & $0.07(0.01)$ & 0.24 & 0.00 & 0.00 & $0.15(0.01)$ \\
\hline \multirow[t]{4}{*}{ PWG } & M1 & $0.15(0.03)$ & $0.02(0.01)$ & 0.13 & $-0.41(0.01)$ & $0.0005(0.001)$ & $0.02(0.01)$ \\
\hline & M2 & $0.15(0.03)$ & $0.02(0.01)$ & 0.13 & $-0.40(0.01)$ & 0.00 & $0.02(0.01)$ \\
\hline & M3 & $0.12(0.03)$ & $0.01(0.00)$ & 0.12 & 0.00 & $0.0003(0.001)$ & $0.02(0.01)$ \\
\hline & M4 & $0.12(0.03)$ & $0.01(0.01)$ & 0.12 & 0.00 & 0.00 & $0.02(0.01)$ \\
\hline
\end{tabular}

$\mathrm{h}^{2}=$ direct additive heritability, $\mathrm{h}^{2}=$ maternal additive heritability, $\mathrm{h}_{\mathrm{t}}^{2}=$ total heritability, $\mathrm{SE}=$ standard error, $\mathrm{r}$ $=$ correlation of direct and maternal effects, $\mathrm{Lc}^{2}=$ cytoplasmic lineage, and $\mathrm{c}^{2}=$ maternal permanent environmental.

For models 1 and 3, the maternal effects were split into their genetic, cytoplasmic, and permanent environmental components, resulting in decreased variance component of the maternal additive genetic effect for BW and PWG. For WW, there was a slight increase in maternal additive genetic variance. Compared to the results obtained from models 1 and 4, the 
proportion of direct additive variance in relation to the phenotypic variance decreased from 1 to $2 \%$ for BW and PWG. In general, the variance component of phenotypic estimates showed similar values, which were consistent with those reported by Bueno et al. (2012) for Nellore cattle in cytoplasmic lineage models.

For BW, the results obtained for the direct heritability coefficient $\left(\mathrm{h}^{2}{ }_{\mathrm{a}}\right)$ were similar between the four models (Table 5), and similar results were presented by Santana et al. (2012) and Regatieri et al. (2012). The estimate for $\mathrm{h}^{2}$ to PWG, was the same as that reported by Tonussi et al. (2015), showing a later response to direct selection. Thus, it is probable that the utilization of Lc models did not interfere with the estimation of genetic parameters. A negative correlation $(-0.05)$ between direct maternal genetic effects was estimated, indicating that the effects of variation and maternal influence differ in direction and magnitude, so the potential for expression of this trait depends to a greater extent on the additive genetic value of each individual.

The estimates for maternal heritability coefficients $\left(\mathrm{h}^{2}{ }_{\mathrm{m}}\right)$ for BW $(0.04)$ were lower than the 0.07 and 0.11, respectively, presented by Eler et al. (2000) and Araújo et al. (2014). In addition, the value obtained for WW was similar to that reported previously between 0.04 and 0.11 by Boligon et al. (2012). As noted in models 1 and 2, the estimated genetic correlation between direct and maternal effect on WW was positive, although the converse $(-0.59)$ was observed by Quintino et al. (2009). This is important as it significantly increased the estimated $\mathrm{h}_{\mathrm{t}}^{2}$, which explains $24 \%$ of the total variance (Figure 1). This confirms that WW clearly shows the potential capacity for maternal effects to influence the offspring. The negative genetic correlation obtained for PWG (-0.41) indicated that maternal ability has little influence and that this is independent to the contribution of their dams on the trait expression.
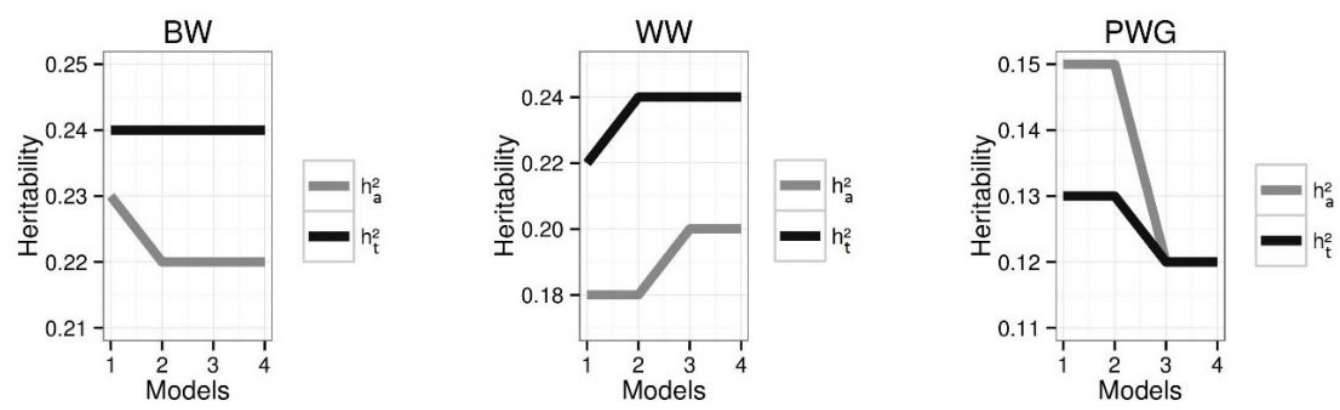

Figure 1. Difference between the total $\left(\mathrm{h}_{\mathrm{t}}\right)$ and direct additive $\left(\mathrm{h}_{\mathrm{a}}{ }_{\mathrm{a}}\right)$ heritability coefficients for $\mathrm{BW}, \mathrm{WW}$, and PWG between models.

For all traits, the Spearman correlation coefficients predicted for the genetic values of breeding were close to 1 , from 0.99 (data not shown) between models 1 and 4 . This indicates the high percentage of animals in the equivalent classification in the selection criteria. These results are consistent with those reported by Malhado et al. (2004), Guterres et al. (2007), and Boligon et al. (2012). In addition, the proportion of conflict selection, that shows divergence in animals classified by model 1 in relation to those classified by model 4 , was $0.3,1.5$, and $1.8 \%$ for $\mathrm{BW}, \mathrm{WW}$, and $\mathrm{PWG}$, respectively. These results indicate that there was a change in the animal sort order, therefore is important for the correct selection of animals.

The results obtained in the present study confirm that the cytoplasmic effect and direct maternal genetic covariance should be considered for BW only. However, consistent with

Genetics and Molecular Research 15 (3): gmr.15038812 
findings from previous studies, it is possible to confirm that cytoplasmic lineage effects and direct and maternal genetic covariance are not significant for post-weaning traits and should not be included in the genetic evaluation (Guterres et al., 2007; Ferreira et al., 2011). Thus, future studies should focus on the use of the mitochondrial genome, which may contribute to a deeper understanding on the cytoplasmic inheritance of complex traits.

In conclusion, for the genetic evaluation of $\mathrm{BW}$, the inclusion of direct-maternal genetic covariance and Lc effects in the animal models is recommended. Despite the short length of mitochondrial DNA, and the small contribution of cytoplasmic lineage effects to the phenotypic variance, is important to account for this effect in genetic evaluation models for pre weaning traits, and are probably not important for post-weaning traits in Nellore cattle.

\section{Conflicts of interest}

The authors declare no conflict of interest.

\section{ACKNOWLEDGMENTS}

Research supported by CAPES (Cordenação de Aperfeiçoamento de Pessoal de Nível Superior). The authors thank Agropecuária CFM Ltda. for the phenotype collection. The authors also thank FAPESP (\#2014/07566-2) for the indirect financial support.

\section{REFERENCES}

Araújo CV, Lobo RB, Figueiredo LGG, Monsquer CJ, et al. (2014). Estimates of genetic parameters of growth traits of Nellore cattle in the Midwest region of Brazil. Rev. Bras. Sau. Prod. Anim 15: 846-853. http://dx.doi.org/10.1590/ $\underline{\text { S1519-99402014000400006 }}$

Boligon AA, Albuquerque LD and Rorato PRN (2008). Associações genéticas entre pesos e características reprodutivas em rebanhos da raça Nelore. Rev. Bras. Zootec. 37: 596-601. http://dx.doi.org/10.1590/S1516-35982008000400002

Boligon AA, Pereira RJ, Ayres DR and Albuquerque LGD (2012). Influence of data structure on the estimation of the additive genetic direct and maternal covariance for early growth traits in Nellore cattle. Livest. Sci. 145: 212-218. http://dx.doi.org/10.1016/j.livsci.2012.02.004

Boligon AA, Sala VE, Mercadante MEZ, Ribeiro EG, et al. (2013). Parâmetros genéticos para diferentes relações de peso ao nascer e a desmama em vacas da raça Nelore. Cienc. Rural 43: 676-681. http://dx.doi.org/10.1590/S0103$\underline{84782013005000019}$

Brown DR, Koehler CM, Lindberg GL, Freeman AE, et al. (1989). Molecular analysis of cytoplasmic genetic variation in Holstein cows. J. Anim. Sci. 67: 1926-1932.

Bueno RS, Mattos EC, Ferraz JBS, Eler JP, et al. (2012). Efeito da linhagem citoplasmática sobre características prédesmame de bovinos Nelore. In: IX Simpósio Brasileiro de Melhoramento Animal, João Pessoa.

Cabrera ME, Garnero AV, Lôbo RB and Gunski RJ (2001). Efecto de la incorporación de la covarianza genética directamaterna en el análisis de características de crescimiento em la raza Nelore. Livest. Res. Rural Dev. 13: 1-6.

Clément V, Bibé B, Verrier E, Elsen JM, et al. (2001). Simulation analysis to test the influence of model adequacy and data structure on the estimation of genetic parameters for traits with direct and maternal effects. Genet. Sel. Evol. 33: 369-395. http://dx.doi.org/10.1186/1297-9686-33-4-369

Carrillo JA and Siewerdt F (2012). Cytoplasmic inheritance has limited importance on early calf growth traits in a closed breeding nucleus Angus herd. J. Genom. Quant. Genet. 4: 8-16.

Dodenhoff J, Van Vleck LD and Wilson DE (1999). Comparison of models to estimate genetic effects of weaning weight of Angus cattle. J. Anim. Sci. 77: 3176-3184.

Eler JP, Ferraz JBS, Golden BL and Pereira E (2000). Influência da Interação touro x rebanho na estimação da correlação entre efeitos genéticos direto e materno em bovinos da raça Nelore. Rev. Bras. Zootec. 29: 1636-1642. http://dx.doi. org/10.1590/S1516-35982000000600007

Genetics and Molecular Research 15 (3): gmr.15038812 
Ferreira JL, de Los Reyes Borjas A, Carvalheiro R and Lôbo RB (2011). Efeitos da inclusão ou não da covariância genética direta-maternal no modelo e dos valores reais das $(\mathrm{co})$ variâncias sobre suas estimativas para peso à desmama em bovinos de corte. Cienc. Anim. Bras 12: 435-442.

Garmyn AJ, Moser DW, Christmas RA and Minick Bormann J (2011). Estimation of genetic parameters and effects of cytoplasmic line on scrotal circumference and semen quality traits in Angus bulls. J. Anim. Sci. 89: 693-698. http:// dx.doi.org/10.2527/jas.2010-3534

Gerstmayr S (1992). Impact of the data structure on the reliability of the estimated genetic parameters in an animal model with maternal effects. J. Anim. Breed. Genet. 109: 321-336. http://dx.doi.org/10.1111/j.1439-0388.1992.tb00412.x

Gibson JP, Freeman AE and Boettcher PJ (1997). Cytoplasmic and mitochondrial inheritance of economic traits in cattle. Livest. Prod. Sci. 47: 115-124. http://dx.doi.org/10.1016/S0301-6226(96)00023-1

Guterres LFW, Rorato PRN, Boligon AA, Wener T, et al. (2007). Efeito da inclusão da covariância genética aditiva diretamaterna no modelo de análise sobre a magnitude das estimativas de parâmetros e valores genéticos preditos para ganho de peso na raça Brangus. Cienc. Rural 37: 809-814. http://dx.doi.org/10.1590/S0103-84782007000300032

Malhado CHM, Lôbo RNB, Filho RM, Facó O, et al. (2004). Efeito da incorporação da covariância entre os efeitos direto e materno sobre a análise para a característica dias para ganhar $160 \mathrm{~kg}$. Braz. J. Vet. Res. Anim. Sci. 41: 14-19. http:// dx.doi.org/10.1590/S1413-95962004000100003

Maniatis N and Pollott GE (2003). The impact of data structure on genetic (co)variance components of early growth in sheep, estimated using an animal model with maternal effects. J. Anim. Sci. 81: 101-108.

Meyer K (1992). Variance components due to direct and maternal effects for growth traits of Australian beef cattle. Livest. Prod. Sci. 31: 179-204. http://dx.doi.org/10.1016/0301-6226(92)90017-X

Mezzadra CA, Melucci LM, Corva PM, López Valiente S, et al. (2005). Effects of cytoplasmic inheritance on preweaning traits of Hereford cattle. Genet. Mol. Biol. 28: 357-362. http://dx.doi.org/10.1590/S1415-47572005000300003

Misztal I, Tsuruta S, Strabel T, Auvray B, et al. (2007). BLUPF90 family of programs. University of Georgia. Available at [http://nce.ads.uga.edu/ ignacy/numpub/blupf90/]. Accessed October 2, 2015.

Mourão GB, Figueiredo LGG, Mattos EC, Ferraz JBS, et al. (2006). LinMat - A maternal and cytoplasmatic line identification software. In: World Congress on Genetic Applied to Livestock Production, 8, Belo Horizonte: SBMA 2006. CD-ROM

Neser FWC, van Wyk JB and Scholtz MM (2014). Evaluation of cytoplasmic genetic effects for production and reproduction traits in Afrikaner cattle. J. Anim. Sci. 44: 85-88.

Oliveira Júnior GA, Eler JP, Ramírez-Díaz J, Ferraz JBS, et al. (2014). Inclusion of weaning management group as a random effect in the genetic evaluation of postweaning traits in Nellore cattle. Trop. Anim. Health Prod. 46: 10311036. http://dx.doi.org/10.1007/s11250-014-0607-4

Pedrosa VB, Eler JP, Ferraz JBS and Pinto LFB (2014a). Utilização de modelos unicaracterística e multicaracterística na estimação de parâmetros genéticos na raça Nelore. Arq. Bras. Med. Vet. Zootec. 66: 1802-1812. http://dx.doi. org/10.1590/1678-6170

Pedrosa VB, Eler JP, Ferraz JBS and Groeneveld E (2014b). Use of weaning management group as a random effect for a more robust estimation of genetic parameters for post-weaning traits in Nellore cattle. Genet. Mol. Res. 13: 70137021.http://dx.doi.org/10.4238/2014.February.21.7

Pun A, Goyache F, Cervantes I and Gutiérrez JP (2012). Cytoplasmic line effects for birth weight and preweaning growth traits in the Asturiana de los Valles beef cattle breed. Livest. Sci. 143: 177-183. http://dx.doi.org/10.1016/j. $\underline{\text { livsci.2011.09.008 }}$

Quintino HP, Ferraz J, Eler JP, Balieiro J, et al. (2009). Linhagem materna: qual a sua influência em características pré e pós desmama em bovinos da raça Nelore? Livest. Res. Rural Dev. 21: 182.

Rao JNK and Scott AJ (1984). On Chi-squared tests for multiway contingency tables with cell proportions estimated from survey data. Ann. Stat. 12: 46-60. http://dx.doi.org/10.1214/aos/1176346391

Regatieri IC, Boligon AA, Baldi F and Albuquerque LGD (2012). Genetic correlations between mature cow weight and productive and reproductive traits in Nellore cattle. Genet. Mol. Res. 11: 2979-2986. http://dx.doi.org/10.4238/2012. May. 10.4

Santana ML, Eler JP, Ferraz JBS and Mattos EC (2012). Genetic relationship between growth and reproductive traits in Nellore cattle. Animal 6: 565-570.http://dx.doi.org/10.1017/S1751731111001856

Tess MW and MacNeil MD (1994). Evaluation of cytoplasmic genetic effects in Miles City Line 1 Hereford cattle. $J$. Anim. Sci. 72: 851-856.

Tonussi RL, Espigolan R, Gordo DG, Magalhães AF, et al. (2015). Genetic association of growth traits with carcass and meat traits in Nellore cattle. Genet. Mol. Res. 14: 18713-18719. http://dx.doi.org/10.4238/2015.December.28.20

Ventura RV, Silva MA, Dionello NL, Magalhaes DFD, et al. (2007). Desenvolvimento do software DRLinhagem para deteç̧ão de linhagens citoplasmáticas e avaliação de seu efeito sobre os pesos à desmama e ao ano de idade de animais Nelore no Centro-Oeste brasileiro. Arq. Bras. Med. Vet. Zootec. 59: 1250-1256. http://dx.doi.org/10.1590/ $\underline{\text { S0102-09352007000500023 }}$

Willham RL (1972). The role of maternal effects in animal breeding. 3. Biometrical aspects of maternal effects in animals. J. Anim. Sci. 35: 1288-1293.

Genetics and Molecular Research 15 (3): gmr.15038812 